\title{
EFFECT OF NON FINANCIAL INFORMATION ON FINANCIAL PERFORMANCE: EVIDENCE FROM TURKEY
}

\author{
Aylin POROY ARSOY * \\ Tuba BORA ** \\ Lale KARABIYIK $* * *$
}

\begin{abstract}
The primary objective of disclosure of financial and non financial information is to inform analysts and investors about the amount, timing and uncertainty of future earnings. The value relevance of financial information provided by financial reports have been attracted many researchers and many of them found the positive relationships. This paper examines whether the level of non financial information disclosure affects the financial performance of companies. There are suggestions in the academic literature that providing additional financial or non financial information decreases information asymmetry between companies and investors, and also enhances corporate transparency. Although it is relatively reasonable to measure the financial performance of a company by indicators; it is not so reasonable to find out indicators to measure the non financial performance of a company. This is why the non financial information results from the organizational, market based, social and intellectual environment of the companies. In our paper, according to the previous literature, initially we indicated "disclosure scores" for BIST 100 companies which refer to their level of non financial information disclosures. We benefited largely from the annual reports to find data concerning non financial disclosure of companies. In our second part of research, we analyzed our data via panel data analysis.
\end{abstract}

Keywords: non financial information, financial information, BIST 100, Turkey

JEL classifications: M40, M41

* Uludağ Üniversitesi, İ.İ.B.F., İşletme Bölümü, aporoy@uludag.edu.tr

** Uludağ Üniversitesi, İ.İ.B.F., İșletme Bölümü, tubabora@uludag.edu.tr

*** Uludağ Üniversitesi, İ.̇̇.B.F., İşletme Bölümü, lale@uludag.edu.tr 


\section{INTRODUCTION}

The emergence of knowledge based economy lead companies to increase their view for disclosing information about their both financial and non-financial trends. Disclosing financial information is formally based on some rules and policies all over the world, i.e. EU directives, international financial reporting and accounting standards. As a part their valuecreation process, producing information on social, environmental and sustainable aspects of their operations comes along with an informal process. These disclosures are achieving through annual reports, corporate governance or social responsibility reports. Although guidelines exist for the production of such non-financial reporting, the adoption of these guidelines is often optional (DG Internal Market, 2011).

Although traditional financial statements present information about the financial position and performance of the company, the researches argued that only financial information is not adequate to portray the corporate value of the company (Arvidsson, 2011; Milost, 2013).

This paper examines whether the level of non financial information disclosure affects the financial performance of companies. In our paper, according to the previous literature, initially we indicated "disclosure scores" for BIST 100 companies which refer to their level of non financial information disclosures. We benefited largely from the annual reports to find data concerning non financial disclosure of companies. In our second part of research, we analyzed our data via panel data analysis.

\section{NON FINANCIAL INFORMATION VERSUS FINANCIAL INFORMATION}

Amir \& Lev (1996) define non-financial information as non-accounting information whereas FASB presents a boarder perspective:

“..non-financial disclosures and metrics include index scores, ratios, counts and other information not presented in the basic financial statements." (FASB, 2001)

Current trends such as globalization, the introduction of new technologies and new businesses and knowledge economy, decrease the value relevance of financial statement information (Orens, \& Lybaert, 2010) that does not include non-financial parameters.

The importance and relevance of non-financial information has been attracted many researchers (Flöstrand, \& Ström, 2006; Amir, \& Lev, 1996; Behn, \& Riley, 1999) To enhance 
traditional financial reporting, academics and policymakers have suggested that financial statement users be provided with nonfinancial performance information that may enhance users' ability to evaluate and predict financial performance (Behn, \& Riley, 1999).

Some of the researchers focused on the components of non-financial disclosure. For example customer satisfaction took much interest. Ittner, Larcker, \& Meyer (1997), found a statistically significant positive relationship between customer satisfaction and a company's future financial performance. Lambert (1998) also points out a positive relationship between customer satisfaction and future financial performance. Anderson, Fornell, \& Mazvancheryl (2004) found a positive relationship between customer satisfaction and shareholder value. However, Mavrinac, \& Seisfeld (1997) found out that institutional investors treat customer satisfaction as a rather non-significant factor.

Financial information that could be provided from financial statements could be easily derivable and thought to be reliable. Financial information has been accepted as the key indicator of company performance and also the most important factor for investment decisions.

From financial statements we can learn about the financial structure, financial performance, liquidity and profitability of the companies. However, from financial statements we cannot read about the company's coexistence with the local community and its wider environment, about the company's technological development, employee satisfaction, health and safety at work, etc. There is also any information on competitive advantages and company's weaknesses, its market share, customer satisfaction, new products, quality control expenses, branch development and the like. Financial statements do not show the value of investment in employees, neither do they show their knowledge and skills (Milost, 2013).

The use of non-financial information has led to the appearance of new types of analysis, known as extra-financial analysis. Thus, enterprise performance is no longer conditioned by financial resources managed and controlled by the entities, but by a complex of intangible resources created by the previous activity of the companies (Popa, Bogdan, \& Balaciu, 2012).

The balanced scorecard is known as the first focus of non-financial information. Kaplan \& Norton (1992) originally introduced the Balanced Scorecard (BSC) to overcome problems that result from a sole focus on financial measures. A BSC enables financial 
performance measures (grouped into a single financial category) and non-financial performance measures (grouped into non-financial categories including customer, internal business process, and learning and growth) to be displayed in combination. The balanced scorecard framework allows to identify the various dimensions of non-financial information related to value creation. It reflects a comprehensive information set on management's initiatives and actions with regard to a firm's human, informational and organizational capital and its financial consequences.

\section{INTERNATIONAL GUIDELINES FOR NON FINANCIAL DISCLOSURE}

However, nowadays non-financial information has been recognized by many international institutions. Many of them prepared guidelines for non-financial reporting.

Among these are:

\section{III.I. OECD guidelines for Multinational Enterprises}

The Guidelines are recommendations addressed by governments to multinational enterprises operating in or from adhering countries. The Guidelines aim to ensure that the operations of these enterprises are in harmony with government policies, to strengthen the basis of mutual confidence between enterprises and the societies in which they operate, to help improve the foreign investment climate and to enhance the contribution to sustainable development made by multinational enterprises (OECD, 2011).

The latest edition of the guidelines extends to 95 pages. They provide voluntary principles and frameworks for responsible business conduct in areas such as employment and industrial relations, human rights, environment, information disclosure, combating bribery, consumer interests, science and technology, competition, and taxation. The guidelines also provide advice on implementation.

\section{III.II. Global Reporting Initiative}

The Global Reporting Initiative (GRI) is a leading organization in the sustainability field. GRI promotes the use of sustainability reporting as a way for organizations to become more sustainable and contribute to sustainable development (www.globalreporting.org). The Sustainability Reporting Framework provides guidance on how organizations can disclose their sustainability performance. It consists of the Sustainability Reporting Guidelines, Sector Supplements and the Technical Protocol. There are in addition sector supplements dealing 
with electrical utilities, financial services, food processing, mining and metals and NGOs. Other sector supplements are being prepared or piloted. Recently 1600 companies worldwide report using GRI standards.

There are a number of other guidelines, generally concentrating on specific aspects of non-financial reporting, brought together by the UN compact - The United Nations Global Compact is a strategic policy initiative for businesses that are committed to aligning their operations and strategies with ten universally accepted principles in the areas of human rights, labour, environment and anti-corruption.

\section{III.III. ISO 26000}

The International Standard ISO 26000, Guidance on social responsibility, provides guidance on reporting social responsibility. It is a non-mandatory standard aimed at all types of organisation to encourage the implementation of best practice in social responsibility worldwide. ISO 26000 provides guidance on how businesses and organizations can operate in a socially responsible way. This means acting in an ethical and transparent way that contributes to the health and welfare of society (www.iso.org).

ISO 26000 provides guidance to all types of organizations, regardless of their size or location, on:

- concepts, terms and definitions related to social responsibility;

- the background, trends and characteristics of social responsibility;

- principles and practices relating to social responsibility;

- the core subjects and issues of social responsibility;

- integrating, implementing and promoting socially responsible behaviour throughout the organization and, through its policies and practices, within its sphere of influence;

- identifying and engaging with stakeholders; and

- communicating commitments, performance and other information related to social responsibility.

\section{III.IV. ILO Core Conventions}

Eight ILO Conventions have been identified by the ILO's Governing Body as being fundamental to the rights of human beings at work, irrespective of levels of development of individual member States. The conventions cover the following areas 
- Forced Labour 1930

- Freedom of Association and Protection of the Right to Organize 1948

- Right to Organize and Collective Bargaining 1949

- Equal remuneration 1951

- Abolition of Forced Labour 1957

- Discrimination (Employment and Occupation) 1958

- Minimum Age Convention 1973

- Elimination of the Worst Forms of Child Labour 1999

\section{III.V. European Commission Directive}

The European Commission adopted on 16 April 2013 a proposal for a directive enhancing the transparency of certain large companies on social and environmental matters (EC, 2013). This Directive amends the Accounting Directives (Fourth and Seventh Accounting Directives on Annual and Consolidated Accounts, 78/660/EEC and 83/349/EEC, respectively). The objective is to increase EU companies' transparency and performance on environmental and social matters, and, therefore, to contribute effectively to long-term economic growth and employment. This legislative initiative is part of the wider EU strategy on CSR and was announced in the 2011 Single Market Act and the 2011-2014 Renewed strategy for Corporate Social Responsibility. It follows the European Parliament's resolutions on CSR adopted in February 2013 (EC, 2014). The rationale behind the proposal is that current legislation (the Accounting Directives), which require companies to disclose certain information on environmental, social and other aspects of their activities where appropriate, has not proved effective. Currently, fewer than $10 \%$ of the largest EU companies disclose such information regularly.

The objective of the new proposal is to increase the transparency and improve the performance of European companies on environmental and social matters, thereby contributing to long-term economic growth and employment. Specifically, the European Commission aims to increase the quantity of reporters and the quality of the information disclosed, and to enhance diversity in the boardroom. According to the provisions, all large companies in the EU (more than 500 employees, $€ 20$ million balance sheet, or $€ 40$ million net turnover) will have to disclose information on (a) policies, (b) risks and (c) results regarding:

- environmental matters 
- $\quad$ social and employee-related aspects

- respect for human rights

- anti-corruption and bribery issues

- diversity on boards of directors

The proposed measure has a non-prescriptive nature and adopts an approach in line with a 'Report or Explain' policy, leaving significant flexibility for companies to disclose relevant information in the way that they consider most useful. To report, companies are encouraged to use recognized international or national guidance and frameworks such as the UNGC Principles, the UN Guiding Principles on Business and Human Rights, the OECD Guidelines for Multinational Enterprises, ISO 26000, the ILO Tripartite Declaration of principles concerning multinational enterprises and social policy, and the Global Reporting Initiative Framework.

The approach ensures administrative burdens are kept to a minimum. The requirements would target around 18.000 large EU companies, while small to medium-sized businesses would be exempt. Additionally, companies which, as part of the annual report, prepare a comprehensive report in the same financial year covering the outlined topics, and relying on the recognized frameworks above, are also exempt from the requirements. As an additional step on $26^{\text {th }}$ February 2014; The European Parliament and the Council have reached agreement on an amendment to existing accounting legislation to improve the transparency of certain large companies on social, environmental and diversity matters.

\section{RESEARCH DESIGN}

\section{IV.I. Sample Selection and Descriptive Statistics}

The study includes 58 firms listed on the Borsa Istanbul 100 (BIST 100) index. We did not include financial companies (banks, insurance companies etc.) to our sample in order to protect the homogenous of our sample.

In order to measure their financial performances ; we include those firms' return on asset, return on equity, return on sales, debt/asset ratio, net sales, total assets, equity and profit variables into the analysis. We obtained the data from the balance sheets dated 31 December 2012 and income statements for the period 1 January 2012- 31 December 2012. 
Table I presents the descriptive statistics of our sample. As presented on the Table I, the mean (median) return on assets is $0.068(0.071)$; the mean (median) return on equity is $0.152(0.120)$; the mean (median) return on sales is $0.162(0.070)$. these variables reflect the profitability and efficiency of your sample firms. As a indicator of financial leverage, the mean (median) debt/asset ratio is 0.474 (0.509) which reflect a rational financial policy. Also the net sales, total assets, equity and profit figures where mentioned in terms of mean median, minimum and maximum values in order to figure out the size of the firms.

Table I: Descriptive Statistics - Financial Performance Bases $\quad(n=58)$

\begin{tabular}{lcccc}
\hline \hline Variable & \multicolumn{2}{c}{ Mean } & \multicolumn{2}{c}{ Maximum } \\
& & Median & Minimum & \\
\hline Return on assets & 0.068 & 0.071 & -0.152 & 0.409 \\
Return on equity & 0.152 & 0.120 & -0.234 & 1.019 \\
Return on sales & 0.162 & 0.070 & -0.175 & 3.032 \\
Debt/asset ratio & 0.474 & 0.509 & 0.105 & 0.884 \\
Net sales & 4.161 .821 .296 & 1.425 .074 .980 & 23.300 .403 & 47.033 .224 .000 \\
Total assets & 3.900 .702 .385 & 2.144 .141 .139 & 47.493 .761 & 18.780 .902 .463 \\
Equity & 1.834 .576 .623 & 957.677 .075 & 38.429 .016 & 12.734 .933 .000 \\
Profit & 290.976 .600 & 90.474 .095 & -112.825 .000 & 2.637 .107 .000 \\
\hline $\mathbf{n = 5 8}$ & \multicolumn{5}{l}{} \\
\hline \hline
\end{tabular}

In order to measure non-financial information, we built a disclosure index based on earlier literature (Banghoj, \& Plenborg, 2008; Binh, 2012). Our disclosure index consists six subcategories of non-financial information (Table II). We use the annual reports for the year 2012 in order to reach the information for disclosure index.

\section{Table II: Subcategories of Non-Financial Information}

\section{CORPORATE INFORMATION}

1.The mission and vision statements

2.Brief history of the corporation (establishment and development)

3.Description of goods and services

4.Analysis of the company's sector

5.Company's achieved awards 
6.Methods of quality control

7.Corporate contribution to the national economy

8.Corporate goals and objectives

9. Strategies taken to achieve corporate goals and objectives

10.Detailed segment performance analysis (based on geographical segment and production segments)

11.Risk measurements (commercial, financial, interest or exchange risks )

\section{COMPETITION AND MARKETING STRATEGIES}

12.Analysis of the company's market share

13.Analysis of the company's competitive advantages

14.Barriers to entry to new markets

15.The market growth rates

16.Change in market shares

17.The impact of competition on profits

18.Marketing strategies

19.Sales and marketing costs

20.Customer turnover rates

21.Customer satisfaction level

22.Revenues from new products/services

23.Amount of new orders placed in current year

FUTURE INFORMATION

24.Development of new products/services

25.Projection of future market share

26.Factors that may affect future performance

27.Sale increasing plans

28.Projection of research and development expenditure

29.Projection of cash flows

30.Planned advertising expenditures

31.Future sales forecast

32.Future profit forecast 


\section{PRODUCTION}

33.Main business of the company

34.Specific characteristics of products /services provided

35.Investments in products

36.Product development cycle

37.Volume of materials consumed

38.Changes in production methods

39. Changes in product materials

40.Inventory turnover rate

\section{BOARD OF DIRECTORS}

41.Names of the members

42.Education qualification of members

43.Professional experiences of members

44.Number of board of directors meetings per year

HUMAN RESOURCES, SOCIAL RESPONSIBILITY AND ENVIRONMENTAL POLICIES

45. Work allocation of directors

46.Education qualification of directors

47.Professional experiences of directors

48.Human resources policies

49.Number of employees

50.Category of employees by sex

51.Education qualification of white collar employee

52.Average wage of employees

53.Average age of employees

54.Employee turnover rate

55.Employee remuneration strategies

56.Policy on employee training

57.Information about safety policy

58.Ethic codes 
59.Environment protection programs

60.Social responsibility projects

61.Data on workplace accidents

Table III presents the mean and median disclosure scores of our sample for the year 2012. The score on human resources, social responsibility and environmental policies is the highest score (mean= 9.33 median=9) suggesting that management gives the most importance for these policies. The score of future information is fairly low (mean=1.22 median=1). This is anxious for companies, hence these low scores indicate fair planning and budgeting activities of firms.

Table III: Six Subcategories of Disclosure Score ( $n=58$ )

\begin{tabular}{lcc}
\hline \hline & Mean & Median \\
\hline Corporate Information (11) & 7,09 & 7 \\
Competition and Marketing Strategies (12) & 3,40 & 3,5 \\
Future Information (9) & 1,22 & 1 \\
Production (8) & 3,78 & 4 \\
Board of Directors (4) & 3,33 & 4 \\
Human Resources, Social Responsibility and Environmental Policies (17) & 9,33 & 9 \\
& & \\
\hline \hline
\end{tabular}

\section{IV.II. Empirical Results}

In this study we used principal component analysis for indicating principal components of financial performance. Principal component analysis (PCA) is a basic multivariate statistical analysis and it aims to derive a small number of independent linear combinations of a set of variables that retain as much information as possible in the original set of variables. PCA is performed on the covariance matrix of the data matrix or it is performed on the correlation matrix of standardized data matrix. One should standardize the data matrix, if the variances of variables differ from each other or if the units of measurement of the variables differ. This is necessary because if one variable has a much larger variance than all other variables, it will dominate the principal component scores regardless of the covariance structure of the original variables. Therefore, choosing to analyze standardized data matrix (studying with the correlation matrix rather than covariance matrix i.e.) involves deciding that all of the variables are equally important (Johnson, 1998). 
Table IV presents the Kaiser-Meyer-Olkin Measure of sampling adequacy (KMO) which is a measure for comparing the magnitudes of observed correlation coefficients with the magnitudes of partial correlation coefficients. The value of the KMO is equal to 0.773 which good to warrant interpretation of results. Moreover, Bartlett's Test of Sphericity is used in order to test the null hypothesis that whether the correlation matrix is an identity matrix. Bartlett's Test of Sphericity with associated probability is less than 0.05 indicates that the correlation matrix is not an identity matrix.

\section{Table IV: KMO and Bartlett's Test of Sphericity}

\begin{tabular}{lr}
\hline \hline Kaiser-Meyer-Olkin Measure of Sampling \\
Adequacy. & 0.773 \\
\hline \hline Bartlett's Test of Sphericity Approx. Chi- & \\
Square & 141.13 \\
p value & 0.00 \\
\hline \hline
\end{tabular}

The communality for a given variable can be interpreted as the proportion of variation in that variable explained by the important principal components. Results in Table V indicate that variance explained by principal components for each one of the original variable is bigger than 0.50 seems appropriate the interpretation of PCA.

Table V: Communalities

\begin{tabular}{ll}
\hline \hline \multicolumn{1}{c}{ Variables } & Variance \\
\hline Return on assets & 0.761 \\
Return on equity & 0.804 \\
Return on sales & 0.874 \\
Debt/Asset ratio & 0.901 \\
Net sales & 0.693 \\
Total assets & 0.870 \\
Equity & 0.698 \\
Profit & 0.734
\end{tabular}

Table VI presents the component matrix. The first principle component has four large loadings which are Total Assets (0.519), profit (0.510) Equity (0.466) and net sales (0.417) and it reflects financial structure and firm size. The second principle component has three 
large loadings which are Return on Assets (0.608), Return on Equity (0.582), Return on Sales (0.433) . This component seems to reflect profitability and productability. The third principal component has one large loading which is debt/asset ratio (0.835) which reflects capital structure of the firm.

\section{Table VI: Communalities}

\begin{tabular}{llll}
\hline \hline Variables & PC 1 & PC 2 & PC 3 \\
\hline Return on assets & 0.170 & $\mathbf{0 . 6 0 8}$ & -0.132 \\
Return on equity & 0.207 & $\mathbf{0 . 5 8 2}$ & 0.333 \\
Return on sales & -0.002 & $\mathbf{0 . 4 3 3}$ & -0.169 \\
Debt/Asset ratio & 0.091 & -0.074 & $\mathbf{0 . 8 3 5}$ \\
Net sales & $\mathbf{0 . 4 1 7}$ & -0.180 & 0.204 \\
Total assets & $\mathbf{0 . 5 1 9}$ & -0.175 & -0.047 \\
Equity & $\mathbf{0 . 4 6 6}$ & -0.176 & -0.311 \\
Profit & $\mathbf{0 . 5 1 0}$ & 0.063 & -0.074 \\
& & & \\
\hline \hline
\end{tabular}

Table VII shows the scores of first three principle components and their weighted sums of our sample firms.

Table VII: Component Scores

\begin{tabular}{lrrrr}
\hline \hline & \multicolumn{3}{c}{ Component Scores } & \\
\hline & $\mathbf{1}$ & $\mathbf{2}$ & $\mathbf{3}$ & Weighted Total \\
ANADOLU EFES & 1.93 & -0.93 & -1.84 & 0.37 \\
AFYON ÇIMMENTO & -2.27 & -2.81 & -1.00 & -2.18 \\
AKENERJİ & -0.77 & -0.52 & 0.75 & -0.40 \\
AKSA & -0.60 & 0.53 & -0.30 & -0.22 \\
AKSA ENERJİ & -0.28 & 0.30 & 0.69 & 0.07 \\
ALKİM KIMMYA & -1.35 & -0.06 & -0.46 & -0.81 \\
ANADOLU CAM & -0.82 & -0.59 & 0.25 & -0.54 \\
ANEL ELEKTRIK & -1.46 & -1.04 & 0.46 & -0.96 \\
ARÇELIK & 1.64 & -0.85 & 0.41 & 0.69 \\
ASELSAN & -0.11 & 0.51 & 0.66 & 0.21 \\
\hline
\end{tabular}




\begin{tabular}{|c|c|c|c|c|}
\hline ANADOLU ISUZU & -1.42 & -0.91 & 0.60 & -0.88 \\
\hline AYGAZ & 0.03 & 0.14 & -1.15 & -0.16 \\
\hline BAGFAŞ & -1.27 & 0.14 & -0.58 & -0.73 \\
\hline BİM MAĞAZALAR & 0.55 & 1.35 & 1.22 & 0.91 \\
\hline BİZİM MAĞAZALARI & -0.91 & 0.23 & 1.22 & -0.16 \\
\hline BRİSA & -0.76 & 0.26 & 0.74 & -0.17 \\
\hline BORUSAN MANNESMANN & -1.04 & -0.58 & 0.48 & -0.61 \\
\hline COCA COLA İÇECEK & 0.27 & 0.21 & 0.34 & 0.27 \\
\hline ÇİMSA & -0.84 & 0.12 & -0.52 & -0.50 \\
\hline ÇELEBİ & -0.85 & 0.41 & 2.11 & 0.09 \\
\hline DOĞUŞ OTOMOTIV & -0.09 & 0.55 & 0.17 & 0.14 \\
\hline ECZACIBAŞI İLAÇ & -0.71 & -0.98 & -1.46 & -0.93 \\
\hline ENKA İNŞAAT & 3.67 & -1.01 & -1.53 & 1.31 \\
\hline EREĞLİ DEMİR ÇELİK & 2.22 & -1.53 & -0.85 & 0.55 \\
\hline FORD OTOSAN & 1.25 & 0.97 & 0.69 & 1.06 \\
\hline GÖLTAŞ ÇİMENTO & -1.36 & -0.31 & -0.39 & -0.87 \\
\hline GOOD-YEAR & -1.06 & 0.26 & -0.27 & -0.53 \\
\hline GÜBRE FABRİK. & -0.38 & 0.44 & 0.76 & 0.07 \\
\hline HÜRRİYET GZT. & -0.63 & 0.61 & 0.28 & -0.09 \\
\hline İHLAS EV ALETLERİ & -1.33 & 0.20 & -0.69 & -0.77 \\
\hline İPEK DOĞAL ENERJİ & -0.85 & -0.51 & -1.53 & -0.89 \\
\hline KARSAN OTOMOTIV & -1.89 & -2.53 & 0.50 & -1.60 \\
\hline KARTONSAN & -1.26 & 0.62 & -1.34 & -0.74 \\
\hline KONYA ÇİMENTO & -1.26 & 0.42 & -1.28 & -0.78 \\
\hline KOZA MADENCİLİK & -0.57 & 0.19 & -1.56 & -0.55 \\
\hline KOZA ALTIN & 0.82 & 4.58 & -1.67 & 1.40 \\
\hline KARDEMIR & -0.47 & 0.34 & 0.05 & -0.14 \\
\hline MİGROS TİCARET & -0.08 & -1.05 & 1.30 & -0.08 \\
\hline MUTLU AKÜ & -1.18 & 0.33 & -0.78 & -0.67 \\
\hline NETAŞ TELEKOM. & -1.30 & -0.49 & 0.19 & -0.77 \\
\hline NET TURİZM & -1.34 & 0.17 & -0.73 & -0.79 \\
\hline OTOKAR & -0.66 & 0.65 & 1.61 & 0.15 \\
\hline PARK ELEK.MADENCILİK & -0.74 & 2.12 & -1.48 & -0.07 \\
\hline OMV PETROL OFISİ & 0.78 & -1.80 & 1.27 & 0.14 \\
\hline SASA POLYESTER & -1.64 & -1.81 & 0.59 & -1.25 \\
\hline
\end{tabular}




\begin{tabular}{lrrrr}
\hline ŞİŞE CAM & 1.02 & -1.13 & -1.00 & 0.01 \\
TURKCELL & 5.76 & -0.72 & -2.23 & 2.35 \\
TÜRK HAVA YOLLARI & 3.82 & -0.97 & 0.66 & 1.84 \\
TEKNOSA İÇ VE DIŞ TİCARET & -0.73 & 0.16 & 1.76 & 0.01 \\
TOFAŞ OTO. FAB. & 0.73 & -0.03 & 0.85 & 0.54 \\
TURCAS PETROL & -1.10 & 3.06 & -1.73 & -0.04 \\
TRAKYA CAM & -0.81 & -0.65 & -1.05 & -0.81 \\
TÜRK TELEKOM & 5.65 & 0.81 & 0.08 & 3.19 \\
TÜRK TRAKTÖR & -0.02 & 2.10 & 0.43 & 0.67 \\
TÜPRAŞ & 5.90 & -1.19 & 1.75 & 3.07 \\
ÜLKER BİSKÜVİ & -0.40 & -0.16 & 0.83 & -0.09 \\
VESTEL & -0.57 & -1.91 & 0.96 & -0.65 \\
ZORLU ENERJİ & 1.25 & 4.24 & 2.70 & 2.38 \\
\hline \hline
\end{tabular}

\section{RESULTS AND CONCLUSION}

To determine the relationship between two indices we used two nonparametric tests namely spearman's rho and runs test. Spearman's rank correlation coefficient is a statistical test for correlation between two rank-ordered scales. The two sets of variables are ranked separately and the differences in rank are calculated for each pair of variables. Table VIII below shows the value of Spearman's rank correlation coefficients between financial indicator index and non-financial information disclosure score subcategories. All of the relationships are positive and statistically significant. The highest coefficient is equal to 0.75 indicates that there is a positive and strong relationship between financial indicator index and human resources, social responsibility and environmental policies subcategory. Also the relationship between financial indicator index - board of directors subcategory and financial indicator index - competition and marketing strategies subcategory show positive and strong relationship with the coefficients of 0.65 and 0.62 respectively. After that, there is a positive relationship between financial indicator index - and production subcategory with the coefficient of 0.51 . The weakest but positive and statistically strong relationship is between financial indicator index and corporate information subcategory with the Spearman's rank correlation coefficient of 0.42 . The relationship between financial indicator index and future information subcategory is also presents a low coefficient of 0.45 . 
Table VIII: Spearman's Rho

\begin{tabular}{lcc}
\hline \hline & Spearman's rho & P value \\
\hline Financial Indicator Index - Corporate Information & 0.42 & 0.00 \\
Financial Indicator Index - Competition and Marketing Strategies & 0.62 & 0.00 \\
Financial Indicator Index - Future Information & 0.45 & 0.05 \\
Financial Indicator Index - Production & 0.51 & 0.02 \\
Financial Indicator Index - Board of Directors & 0.65 & 0.03 \\
Financial Indicator Index - Human Resources, Social Responsibility & 0.75 & 0.00 \\
and Environmental Policies & & \\
\hline \hline
\end{tabular}

The main purpose of this study is to investigate financial and non-financial performance relationship with in the context of developing country conditions. In order to perform our analysis, we structured a non-financial disclosure index consisting six subcategories of non-financial information. Our results show that subcategories of nonfinancial information and our financial indicators have positive correlations.

In general, our analysis indicates that there is a remarkable positive relationship between financial indicators and non-financial information disclosed by the sample firms listed in BIST 100. Furthermore, the firms who have better financial indicator performance; they also have better non-financial disclosure scores.

The limitation of the study is the lower number of the observed firms; however this problem exists as a major shortcoming of similar studies in developing countries.

\section{Acknowledgments}

This study was supported by The Commission of Scientific Research Projects of Uludag University, KUAP(İ)-2013/35. 


\section{REFERENCES}

Amir, E., \& Lev, B. 1996. Value relevance of non financial information: the wireless communications industry. Journal of Accounting and Economics, 22(3): 3-30.

Anderson, E.W., Fornell, C., \& Mazvancheryl, S.K. 2004. Customer satisfaction and shareholder value. Journal of Marketing, 68(4): 172-185.

Arvidsson, S. 2011. Disclosure of non-financial information in the annual report: a management-team perspective. Journal of Intellectual Capital, 12(2): 277-300.

Banghoj, J., \& Plenborg, T. 2008. Value relevance of voluntary disclosure in the annual report. Accounting \& Finance, 48: 159-180.

Behn, B. K., \& Riley R. A. 1999. Using non-financial information to predict financial performance: the case of us airline industry. Journal of Accounting, Auditing and Finance, 14(29): 29-56.

Binh, T. Q. 2012. Voluntary disclosure information in the annual reports of non financial listed companies: the case of Vietnam. Journal of Applied Economics and Business Research, 2(2): 69-90.

DG Internal Market. 2011. Framework contract for projects relating to evaluation and impact assessment activities of directorate, general for internal market and services, disclosure of non-financial information by companies; final report.

European Commission - IP/13/330, 16/04/2013, Commission moves to enhance business transparency on social and environmental matters.

European Commission - STATEMENT/14/29, 26/02/2014, Disclosure of non-financial information by certain large companies: European Parliament and Council reach agreement on commission proposal to improve transparency.

FASB, 2001. Special report on business and financial reporting, challenge from the new economy, 1-18.

Flöstrand, P., \& Ström, N. 2006. The valuation relevance of non-financial information. Management Research News, 29(9): 580-597.

Ittner, C.D., Larcker, D.F., \& Meyer, M. W. 1997. Performance, compensation, and the balanced scorecard. technical report, University of Pennsylvania. 
Johnson D. E. 1998. Applied multivariate methods for data analysis, London, International Thompson Publishing.

Kaplan, R.S., \& Norton, D.P. 1992. The balanced scorecard: measures that drive performance. Harvard Business Review, 70(1): 71-79.

Lambert, R.A. 1998. Customer satisfaction and future financial performance discussion of are nonfinancial measures leading indicators of financial performance? an analysis of customer satisfaction. Journal of Accounting Research, 36(1): 37-46.

Mavrinac, S., \& Seisfeld, T. 1997. Measures that matter an exploratory investigation of Investor's information needs and value priorities, working paper, University of Western Ontario.

Milost, F. 2013. Information power of non financial performance measures. International Journal of Business Management \& Economic Research, 4(6): 823-828.

OECD, 2011. OECD Guidelines for multinational enterprises, OECD Publishing.

Orens, R., \& Lybaert, N. 2010. Determinants of sell-side financial analysts' use of nonfinancial information. Accounting and Business Research, 40(1): 39-53.

Popa, D., Bogdan, V., \& Balaciu, D. 2012. Aspects of company performance analysis based on relevant financial information and non financial information, Annals of the University of Oradea, Economic Science Series, 21(1): 956-961.

www.globalreporting.org

www.iso.org 